Adam Staliński*

\title{
UWARUNKOWANIA PRAWNE I POLITYCZNE A KONKURENCYJNOŚĆ BRANŻY ELEKTROENERGETYCZNEJ OZE W POLSCE I W NIEMCZECH
}

\section{Wprowadzenie}

Celem artykułu jest przeanalizowanie oddziaływania uwarunkowań prawnych i politycznych zachodzących w Polsce i w Niemczech na konkurencyjność sektora odnawialnych źródeł energii (OZE) w zakresie wytwarzania energii elektrycznej. Analiza obejmuje również oddziaływanie rządów obu państw na wspomniany sektor poprzez ich wpływ na energetykę opartą na węglu. Modelem stanowiącym trzon analizy jest rozszerzony diament przewagi konkurencyjnej narodów M.E. Portera, choć jego zakres został tu ograniczony do jedynie czynnika rządowego i jego wpływu na pozostałe komponenty modelu. Artykuł powstał na bazie analizy literaturowej tekstów naukowych, raportów rządowych i pochodzących z organizacji pozarządowych, aktów prawnych i danych z urzędów statystycznych. Prezentuje stan wiedzy aktualny na 30 września 2016 r.

\section{Model konkurencyjności sektora}

Najbardziej liczącym się modelem tłumaczącym składowe międzynarodowej konkurencyjności sektora jest opracowany przez M.E. Portera tzw. diament określający determinanty przewagi narodu ${ }^{1}$. Pod pojęciem narodu Porter rozumie gospodarkę danego państwa, a ściślej analizowany sektor.

* Wydział Gospodarki Międzynarodowej, Uniwersytet Ekonomiczny w Poznaniu.

1 B. Jankowska, Konkurencyjność w ujęciu mezoekonomicznym, [w:] Kompendium wiedzy o konkurencyjności, red. M. Gorynia, E. Łaźniewska, Wydawnictwo Naukowe PWN, Warszawa 2010, s. 100. 
Porter wyróżnił sześć sfer (cztery podstawowe i dwie dodatkowe), które oddziałują na firmy, tworząc przewagę sektora. Sukces sektora zależy od korzystnego układu tych czynników, choć one go nie gwarantują. Każdy z tych czynników ma inne znaczenie w różnych sektorach. Wszystkie składowe tworzą system i są od siebie zależne, wpływając na siebie nawzajem². Sfery te obejmują:

- Warunki czynników produkcji, takie jak np. zasoby ludzkie (łącznie z kosztami pracy i poziomem wykwalifikowania), infrastrukturę potrzebną do działania, zasoby wiedzy, kapitał czy warunki naturalne ${ }^{3}$.

- Warunki popytowe - jakie są oczekiwania klientów. Firmy zdobywają przewagę tam, gdzie są w stanie lepiej sprostać ich wymogom. Mniej ważna jest skala popytu, bardziej jego charakter ${ }^{4}$.

- Sektory pokrewne i wspierające - na możliwość osiągnięcia przewagi konkurencyjnej ma wpływ także bliskość i obfitość innych podmiotów, które nie są konkurentami w analizowanym sektorze, ale funkcjonują w nim i biorą udział w tworzeniu łańcucha wartości. Najlepiej, gdy te firmy cechują się wysokim poziomem międzynarodowej konkurencyjności ${ }^{5}$.

- Strategia, struktura i rywalizacja firm - ile przedsiębiorstw działa w sektorze, jak duże one są, jakie strategie konkurowania przyjęly, jak ostra jest rywalizacji itp. ${ }^{6}$

- Szansa/przypadek - pod tym pojęciem kryje się wszystko, czego nagłe pojawienie się znacząco zmienia sytuację w sektorze, np. przełomowe wynalazki, zmiany $\mathrm{w}$ trendach, znaczące zmiany na rynkach finansowych, przełomowe decyzje polityczne, przewroty, wojny ${ }^{7}$.

- Rola rządu - odnosi się do pozostałych czynników, na które może on wpływać pozytywnie lub negatywnie. Dotacje, przepisy podatkowe, uregulowania dotyczące rynków kapitałowych oraz edukacji itp. mogą znacząco zmienić obecny układ czynników. Strategia firm i struktura sektora mogą się zmienić pod wpływem m.in. polityki podatkowej i prawa antymonopolowego, sektory pokrewne i wspierające natomiast na skutek regulacji w dziedzinach takich jak np. wsparcie dla dostawców. Dodatkowo, rząd często jest największym na rynku odbiorcą i jego decyzje zakupowe znacząco kształtują popyt - jeśli zgłasza on zapotrzebowanie na najnowsze i najwydajniejsze rozwiązania, stymuluje wzrost konkurencyjności .

2 Ibidem, s. 71-73.

3 M.E. Porter, The competitive advantage of nations, Macmillan Press, London, Basingstoke 1991, s. $80-82$.

4 Ibidem, s. 86-89.

Ibidem, s. 100-104.

Ibidem, s. 117-121.

Ibidem, s. 124-126.

Ibidem, s. 126-128. 


\section{Kierunki rozwoju OZE w Polsce i Niemczech}

Kierunki rozwoju polityki energetycznej w ostatnich latach bardzo się różniły między Polską a Niemcami. Niemcy są jednym ze światowych liderów wdrażania OZE, a ich polityka przejścia na nie jest nazywana Energiewende (zwrot energetyczny) ${ }^{9}$. Ich celem jest osiągnięcie do 2050 r. 80\% udziału OZE w bilansie energetycznym. Odbywa się to nawet kosztem wczesnego wycofywania elektrowni atomowych ${ }^{10}$. Początki Energiewende miały miejsce w latach 70 . XX w. i wynikały nie tylko ze względów ekologicznych, ale i z niezadowolenia z dominacji wielkich koncernów energetycznych. Ludzie z różnych środowisk (jak pastorzy, rolnicy czy naukowcy) wspólnie sprzeciwiali się nowym wielkim elektrowniom, uważając, że lepszym rozwiązaniem będzie rozproszona, lokalna produkcja ${ }^{11}$. W $1980 \mathrm{r}$. trzech badaczy zaangażowanych w ten ruch wydało książkę, w której po raz pierwszy pojawiło się słowo Energiewende (jako Energie-Wende) ${ }^{12}$. Rozwój OZE rozpoczął się powoli. W $1991 \mathrm{r}$. uchwalono pierwsze na świecie taryfy gwarantowane dla nich. Mimo to nawet w 1994 r., gdy 3\% elektryczności w Niemczech pochodziło z hydroelektrowni, koncerny energetyczne uważały, że udział OZE nigdy nie przekroczy $4 \%{ }^{13}$. Jednym z bardziej przełomowych momentów w niemieckich dążeniach do przejścia energetyki na OZE była uchwalona w marcu 2000 r. ustawa o odnawialnych źródłach energii, Erneuerbare-Energien-Gesetz (EEG), która do 2013 r. stała się wzorem dla podobnych aktów prawnych w ponad 40 państwach ${ }^{14}$. W 2014 r. nastąpiła znaczna nowelizacja, a na 2016 r. zaplanowano kolejną ${ }^{15}$.

9 IRENA (International Renewable Energy Agency), Renewable Energy Prospects: Germany, REmap 2030 analysis, Abu Dhabi 2015, s. 1.

10 J. Olszyński, Nowe elementy w relacjach polsko-niemieckich w zakresie polityki europejskiej, [w:] Nowe zjawiska w gospodarce Niemiec i polsko-niemieckich stosunkach gospodarczych, red. J. Olszyński, A. Bielig, Oficyna Wydawnicza SGH, Warszawa 2014, s. 573.

11 C. Morris, Chapter 7 - Germany's Energiewende: Community-Driven Since the 1970s, [w:] Global Sustainable Communities Handbook. Green Design Technologies and Economics, red. C. Woodrow, Elsevier 2014, s. $105-107$.

12 F. Krause, H. Bossel, K.F. Müller-Reißmann, Energie-Wende: Wachstum und WohlstandohneErdöl und Uran, Frankfurt am Main 1980

13 C. Morris, op.cit., s. 108.

14 R. Beveridge, K. Kern, The 'Energiewende' in Germany: Background, Development and Future Challenges, „Renewable Energy Law and Policy Review” Vol. 4, Iss. 1, 2013, s. 3-12.

15 Gesetzentwurf der Bundesregierung Entwurfeines Gesetzes zur Einführung von Ausschreibungen für Strom aus erneuerbaren Energien und zuweiteren Änderungen des Rechts der erneuerbaren Energien (Erneuerbare-Energien-Gesetz - EEG 2016), http://www.bmwi.de/BMWi/Redaktion/PDF/G/gesetzentwurf-ausschreibungen-erneuerbare-energien-aenderungen-eeg-2016, property=pdf,bereich=bmwi2012, sprache $=$ de, $r w b=$ true.pdf [dostęp 29.09.2016]. 
Niemcy znacznie wyprzedziły unijne wymogi dotyczące wdrażania OZE i same miały spory udział w kształtowaniu polityki UE w tej kwestii. Choć dyrektywa 2009/28/WE ${ }^{16}$ nakłada na Niemcy obowiązek produkcji minimum $18 \%$ energii z OZE do 2020 r., niezależnie od niej władze niemieckie wyznaczyły sobie same cel osiągnięcia w tym czasie 30\% udziału produkcji z OZE energii elektrycznej ${ }^{17}$. Został on osiągnięty już w pierwszej połowie $2015 \mathrm{r} .{ }^{18}$ Według prognoz IRENA oraz BBE i BSW w 2030 r. udział ten będzie przekraczał 50\%, zaś według SRU oraz FVEE i ISE w 2050 r. 100\% energii elektrycznej w Niemczech będzie produkowane z odnawialnych źródeł ${ }^{19}$. Dla porównania, w 2004 r. było to tylko $9,4 \%^{20}$.

Do końca lat 90. niemal cała produkcja elektryczności z OZE w Niemczech pochodziła z hydroelektrowni. Od początku XXI w. szybko znaczenia zaczęły nabierać wiatraki, kilka lat później biomasa, a następnie fotowoltaika, choć ona na dobre ekspansję rozpoczęła dopiero w okolicach 2010 r. ${ }^{21}$ Obecnie rozwój OZE w Niemczech opiera się przede wszystkim na fotowoltaice i energii wiatrowej, czyli źródłach o zmiennej podaży ${ }^{22}$ (a także na biomasie ${ }^{23}$, choć to rzadziej się podkreśla, ale też potencjał do większego wzrostu jest tu bardzo ograniczony). Znaczący udział tych źródeł destabilizuje jednak system elektroenergetyczny, gdyż nie zapewniają one ciągłości podaży, a zwłaszcza dostosowania jej do popytu. Zapewnienie stałości dostaw energii i w ilości takiej, jaka akurat jest potrzebna, wiąże się w takiej sytuacji z wysokimi kosztami magazynowania i odtwarzania mocy. Jeszcze innym sposobem na łagodzenie tego problemu jest połączenie sieci wielu państw i wzajemne przepływy wyrównujące okresowe nierównowagi. Tę opcje wybrały Niemcy i obecnie bardzo naciskają one na to, by podobny kierunek rozwoju obrały również inne państwa, a także prowadząc do budowy interkonektorów i liberalizacji rynków ${ }^{24}$.

16 Dyrektywa Parlamentu Europejskiego i Rady 2009/28/WE z dnia 23 kwietnia 2009 r. w sprawie promowania stosowania energii ze źródeł odnawialnych zmieniająca i w następstwie uchylająca dyrektywy 2001/77/WE oraz 2003/30/WE, DzU UE L 140 z 5.06.2009, s. 16-62, zał. 1.

17 F. Julien, M. Lamla, Competitiveness of Renewable Energies Comparison of Major European Countries, European University Viadrina Frankfurt (Oder), Department of Business Administration and Economics, „Discussion Paper” No. 302, 2011, s. 3; W. Bayer, Energie auf einenBlick, Statistisches Bundesamt, Wiesbaden 2009, s. 34.

18 IRENA, Renewable Energy Prospects, op.cit., s. 1.

19 H. Wirth, Recent Facts about Photovoltaics in Germany, Fraunhofer ISE, Freiburg 2016, s. 57.

20 Eurostat, Electricity generated from renewable sources, 2016, http://ec.europa.eu/eurostat/tgm/table. do? tab $=$ table\&init $=1$ \&language $=$ en \&pcode $=$ tsdcc330\&plugin $=1$ [dostęp 27.09.2016].

21 E. Bayer, Report on the German power system, Agora Energiewende, Berlin 2014, s. 32.

22 IRENA, Renewable Energy Prospects..., op.cit., s. 2; D. Buchan, The Energiewende - Germany's gamble, Oxford Institute for Energy Studies, Oxford 2012, s. 4.

23 E. Bayer, Report on the German..., op.cit., s. 23.

24 J. Olszyński, op.cit., s. 574. 
Polska jest obecnie na znacznie mniej zaawansowanym etapie w kwestii rozwoju OZE, zarówno pod względem stopnia wykorzystania, jak i prawodawstwa oraz ich miejsca w polityce energetycznej. Ustawę o odnawialnych źródłach energii uchwalono w Polsce dopiero 20 lutego $2015 \mathrm{r}^{25}$ Od tego czasu już dwukrotnie ją zmieniano - 29 grudnia 2015 r. ${ }^{26}$ i 22 czerwca 2016 r. ${ }^{27}$ Brak poświęconych tej kwestii uregulowań prawnych nie przeszkadzał jednak w rozwoju tego sektora. Nie działo się to jednak na taką skalę jak w Niemczech, a polityka energetyczna prowadzona przez dotychczasowe rządy nie była nastawiona na szczególny rozwój OZE. Za czasów PO/ PSL (do 2015 r.) podjęto decyzję o budowie pierwszej polskiej elektrowni atomowej i pokładano wielkie nadzieje w gazie łupkowym ${ }^{28}$ (którego, jak się później okazało, w Polsce nie ma za wiele ${ }^{29}$ ). Rząd PiS-u natomiast postrzega węgiel jako jedyne możliwe źródło energii, na które warto zwracać uwagę i rozwijać, m.in. w celu ratowania na siłę upadającego górnictwa ${ }^{30}$.

W roku 2004 w Polsce wytwarzanie energii elektrycznej z OZE było oparte przede wszystkim na energii wodnej i biomasie, które razem odpowiadały za ponad 95\% produkcji. W ciągu następnych 10 lat nominalna produkcja energii $z$ wody pozostawała na zbliżonym poziomie, jednak udział biomasy systematycznie wzrastał. W międzyczasie znacząco zwiększyła się produkcja energii wiatrowej, notując 54-krotny nominalny wzrost, zaś jej względny udział zwiększył się z 4,63\% do 38,69\%. W latach 2009-2014 wiatraki odpowiadały za 59,1\% wzrostu produkcji elektryczności z OZE w Polsce ${ }^{31}$. Tak więc w ostatnich latach urzeczywistnienie celu dotyczącego udziału OZE opierała się głównie na energii wiatrowej. Jeszcze w 2015 r. wydawało się, że ten kierunek rozwoju zostanie utrzymany w najbliższych latach, jednak zmiana władzy w Polsce jesienią 2015 r. wiązała się również ze znaczącą zmianą polityki energetycznej. W zakresie OZE przejawiła się ona w ustawie o zmianie ustawy o odnawialnych źródłach energii, która została przyjęta 22 czerwca 2016 r. (z nielicznymi wyjątkami weszła w życie 1 lipca 2016 r.), a także uchwaleniu 20 maja 2016 r. ustawy o inwestycjach w zakresie elektrowni wiatrowych (weszła w życie 16 lipca 2016 r.). Minister energii, Krzysztof Tchórzewski, podsumował swoją politykę w słowach „Mniej

25 Ustawa z dnia 20 lutego 2015 r. o odnawialnych źródłach energii, DzU 2015, poz. 478 z późn. zm.

26 Ustawa z dnia 29 grudnia 2015 r. o zmianie ustawy o odnawialnych źródłach energii oraz ustawy - Prawo energetyczne, DzU 2015, poz. 2365.

27 Ustawa z dnia 22 czerwca 2016 r. o zmianie ustawy o odnawialnych źródłach energii oraz niektórych innych ustaw, DzU 2016, nr 0, poz. 925.

28 J. Olszyński, op.cit., s. 573.

29 M. Graniszewska, Szef PGNiG gotów gasić światło w łupkach, „Puls Biznesu” nr 88, 2016, s. 4.

30 M. Graniszewska, Polska kontra świat i liczby, „Puls Biznesu” nr 43, 2016, s. 8.

31 GUS, Energia ze źródeł odnawialnych w 2014 r., Warszawa 2015, s. 39, 57. 
wiatraków, więcej biogazowni”32. Te dwa źródła energii zostały bowiem objęte największymi zmianami - wiatrowa została znacznie ograniczona (poprzez wprowadzenie wymogu minimalnej odległości od budynków mieszkalnych i form ochrony przyrody jako dziesięciokrotność całkowitej wysokości wiatraków ${ }^{33}$, która spowodowała, że bardzo trudno w Polsce znaleźć miejsce spełniające te wymogi), zaś dla biogazowni stworzono korzystniejsze niż przedtem warunki. Najważniejszym powodem takiego przesunięcia była kwestia stabilności dostaw prądu, której wiatraki nie gwarantują, generując duże koszty rezerwowych mocy ${ }^{34}$. Tak zwana gorąca rezerwa, czyli stan utrzymywania pełnej gotowości do natychmiastowego rozpoczęcia produkcji prądu w elektrowniach cieplnych, spala paliwo, ponosząc z tego tytułu koszty, a nie przynosząc przychodów $\mathrm{z}$ uwagi na wyłączone turbiny, jest według niemieckiej organizacji VGB skupiającej wytwórców w 32 państwach wymagana w przypadku elektrowni wiatrowych na poziomie 95\% mocy zainstalowanej wiatraków ${ }^{35}$. Biogazownie, mogąc zaś produkować prąd cały czas i dostosowywać swoją produkcję w zależności od zmieniającego się zapotrzebowania, wychodzą naprzeciw tym problemom, dlatego bardzo dobrze wpisują się w oczekiwania wobec elektrowni i dlatego nastąpiło przesunięcie wsparcia rządu w ich kierunku, choć na razie ograniczone w stosunku do potrzeb.

\section{Dotacje do bieżącej produkcjiprądu elektrycznego z OZE}

Zarówno w Polsce, jak i w Niemczech bieżąca produkcja prądu elektrycznego z OZE otrzymuje znaczące wsparcie, które w istotny sposób poprawia jej konkurencyjność.

Niemiecki system wsparcia bieżącej produkcji energii elektrycznej z OZE od wejścia w życie ustawy o OZE z 2000 r. opiera się na taryfach gwarantowanych. Producentom prądu z odnawialnych źródeł zapewnia się przez 20 lat określone wynagrodzenie na każdą wytworzoną kilowatogodzinę ${ }^{36}$. Poprzez dostawców prądu, ich kosztami obarcza się końcowych użytkowników w formie nałożenia na sprzedawany

32 IAR, Tchórzewski: Rząd będzie wspierał biogazownie, Bankier.pl, 28 grudnia 2015, http://www.bankier. pl/wiadomosc/Tchorzewski-Rzad-bedzie-wspieral-biogazownie-3462840.html [dostęp 28.09.2016].

33 Ustawa z dnia 20 maja 2016 r. o inwestycjach w zakresie elektrowni wiatrowych, art. 4, ust. 1-2, DzU 2016, poz. 961.

34 IAR, Tchórzewski..., op.cit.

35 T. Popławski, K. Dąsal, J. Łyp, Problematyka prognozowania mocy i energii pozyskiwanych $z$ wiatru, „Polityka Energetyczna” t. 12, z. 2/2, 2009, s. 511-523.

36 Federal Ministry for Economic Affairs and Energy, Making a success of the energy transition, Berlin 2015, s. 6-7. 
prąd opłaty OZE ${ }^{37}$. Nie wszyscy konsumenci ją jednak płacą w takiej wysokości. Znaczące zwolnienia - prawie całości tej opłaty, jak również z opłaty sieciowej - otrzymują podmioty zużywające najwięcej elektryczności ${ }^{38}$. Sprawia to, że ciężar utrzymywania OZE spada na indywidualnych odbiorców w nieproporcjonalnie większym stopniu niż wynosi ich zużycie, dzięki czemu mogą oni być mniej pozytywnie nastawieni do OZE, postrzegając je jako bardzo kosztowne.

Wprowadzenie dopłat spowodowało szybki rozwój OZE, a to poskutkowało znacznym wzrostem całkowitych sum wsparcia, a co za tym idzie wzrost jednostkowego kosztu, czyli opłaty OZE. W2000 r. wyniosła ona 0,19 eurocentów za kWh, w 2005 r. $-0,70$ c/kWh, w 2010 r. - 2,05 c/kWh, a w 2014 r. - 6,24 c/kWh ${ }^{39}$.

Koszty utrzymywania tego systemu zaczęły ciążyć tak bardzo, że coraz większą uwagę zaczęto przywiązywać do efektywności kosztowej. Podkreślone to zostało m.in. przy okazji zamykania elektrowni atomowych - że skoro OZE mają stanowić docelowo cały rynek, muszą oferować energię po akceptowalnych przez odbiorców cenach $^{40}$. Tymczasem rozwojowi OZE w Niemczech towarzyszy stały spadek hurtowych cen elektryczności. Na początku 2007 r. prąd kosztował około 80 euro/MWh w godzinach szczytu i około 50 euro/MWh w godzinach najniższego zużycia. Pod koniec 2014 r. wynosiły one odpowiednio około 42 euro/MWh i 35 euro/MWh ${ }^{41}$. Jest to wywołane wzrostem podaży energii z OZE przy niewzrastającym popycie ${ }^{42}$. Nie oznacza to jednak spadku cen dla końcowych odbiorców. W tym samym czasie koszty dla średniej wielkości gospodarstw domowych wzrosły z 194,8 euro/MWh do 298,1 euro/MWh ${ }^{43}$.

Wzrost kosztów prądu w związku z dopłatami do produkcji spowodował wprowadzenie w $2014 \mathrm{r}$. zmian w prawie. Nowa ustawa o OZE (tzw. EEG 2.0) weszła w życie 1 sierpnia 2014 r. Dopłaty skupiły się wówczas na energii wiatrowej i słonecznej - ze względu na niskie koszty jednostkowe ${ }^{44}$, co sprawiło, że rok 2015 był pierwszym, w którym opłata OZE spadła - z 6,24 c/kWh do 6,17 c/kWh ${ }^{45}$. W 2016 r. wyniosła ona już jednak $6,354 \mathrm{c} / \mathrm{kWh}^{46}$.

37 Gesetzfür den AusbauerneuerbarerEnergien 2014, $\$ 60$.

38 W. Bayer, Energie auf einen Blick, Statistisches Bundesamt, Wiesbaden 2009, s. 23-24.

39 Federal Ministry for Economic Affairs and Energy, Making a success..., op.cit., s. 8.

40 D. Buchan, op.cit., s. 13.

41 W. Bayer, Energie auf einen Blick, op.cit., s. 21.

42 Ibidem, s. 22.

43 Eurostat, Electricity prices by type of user, 2016, http://ec.europa.eu/eurostat/tgm/table.do?tab=table\&init $=1$ \&language $=$ en \&pcode $=$ ten00117\&plugin $=1$ [dostęp 14.08.2016].

44 Federal Ministry for Economic Affairs and Energy, Making a success..., op.cit., s. 7.

45 Ibidem, s. 8

46 Bundesnetzagentur, Pressemitteilung. EEG-Umlage auf stabilemNiveau, Bonn 2015, 15.10.2015 [dostęp 28.09.2016]. 
Latem 2016 r. przygotowano kolejną znaczną zmianę w ustawie o odnawialnych źródłach energii ${ }^{47}$ (tzw. EEG 3.0). Wprowadza ona od 2017 r. system aukcyjny, polegający na ogłaszaniu przetargów na dostawy energii. Ma to na celu wspieranie tych producentów, którzy będą oferować najtańszy prąd, by możliwie najbardziej ograniczyć wydatki na ten cel. Stosowanie aukcji będzie jednak ograniczone tylko do energii wiatrowej (zarówno na lądzie, jak i na morzu), fotowoltaiki oraz biomasy, i to tylko w zakresie instalacji o mocy minimum $750 \mathrm{~kW}$, a w przypadku biomasy $150 \mathrm{~kW}^{48}$. W przypadku pozostałych źródeł nie wprowadzono aukcji, gdyż mają one sens (czyli wywołują rywalizację cenową) tylko wtedy, gdy w danym segmencie panuje duża konkurencja, a w pozostałych jej nie $\mathrm{ma}^{49}$. O wysokości dopłat w zakresie technologii podlegających aukcjom będzie więc decydować rozstrzygnięcie tychże aukcji ${ }^{50}$.

System wspierania bieżącej produkcji energii elektrycznej z OZE w Polsce opiera się na certyfikatach pochodzenia. Polega on na tym, że producenci prądu z OZE otrzymują świadectwa potwierdzające sposób wytworzenia go. Są one obiektem zbytu, a kupującymi są odbiorcy przemysłowi z pewnej grupy dziedzin działalności (wymienionych w art. 52, ust. 6 ustawy o OZE) zużywający co najmniej $100 \mathrm{GWh}$ rocznie oraz (przede wszystkim) dystrybutorzy energii elektrycznej sprzedający ją końcowym odbiorcom innym niż ww. odbiorcy przemysłowi. Są bowiem zobowiązani uzyskiwać i przedstawiać prezesowi Urzędu Regulacji Energetyki (URE) do umorzenia świadectwa pochodzenia energii z OZE wytworzonej na terenie Polski lub jej wyłącznej strefy ekonomicznej ${ }^{51} \mathrm{w}$ ilości zależnej od ich zużycia i sprzedaży energii ${ }^{52}$. W przeciwnym razie muszą uiścić opłatę zastępczą (jest to dopuszczalne tylko jeśli nie było możliwości zakupu świadectw na sześciu sesjach, w których dany podmiot składał zlecenia ${ }^{53}$, lub gdy ich cena jest wyższa niż opłata zastępcza ${ }^{54}$ ), która wynosi 300,03 zł/MWh ${ }^{55}$. Zmiana ustawy o OZE z 22 czerwca 2016 r. wprowadziła ponadto nowy rodzaj świadectw - dla energii elektrycznej wytworzonej z biogazu rolniczego oraz dla pozostałej energii elektrycznej ${ }^{56}$. Ma to zwiększyć dochody właścicieli biogazowni, których potencjał spadł na skutek ogólnej nadpodaży certyfikatów.

\footnotetext{
47 Gesetzentwurf der Bundesregierung..., op.cit.

48 Bundesministerium für Wirtschaft und Energie, EEG-Novelle 2016. Kernpunkte des Kabinettbeschlusses vom 8.06.2016, http://www.bmwi.de/BMWi/Redaktion/PDF/E/eeg-novelle-2016-kernpunkte-des-kabinettbeschlusses, property=pdf,bereich=bmwi2012, sprache=de,rwb=true.pdf [dostęp29.09.2016].

49 Gesetzentwurf der Bundesregierung..., op.cit., s. 173.

50 Federal Ministry for Economic Affairs and Energy, Making a success..., op.cit., s. 7.

51 Ustawa z dnia 20 lutego 2015 r. o odnawialnych źródłach energii, art. 52, ust. 1-2, op.cit.

52 Ibidem, art. 53 i 59.

53 Ibidem, art. 47 , ust. 7.

54 Ibidem, art. 47, ust. 2.

55 Ibidem, art. 56.

56 Ustawa z dnia 22 czerwca 2016 r. o zmianie..., art. 1, p. 26, op.cit.
} 
Wymóg ich skupu został bowiem określony na za niskim poziomie i producenci nie są w stanie sprzedać wszystkich, dlatego ich ceny mocno spadły.

Świadectwa pochodzenia nie przysługują m.in., gdy w godzinach wytworzenia prądu średnie jego ceny na giełdzie były niższe od zera przez co najmniej 6 kolejnych godzin ${ }^{57}$. W Niemczech takie ceny już się zdarzają w momentach nadpodaży prądu z OZE ${ }^{58}$, stanowiąc ogromny problem dla operatorów sieci. Wynika to z niestabilności systemu, bardzo rozregulowanego na skutek dużego udziału energetyki wiatrowej i słonecznej o trudno przewidywalnej podaży. W Polsce brak certyfikatów w godzinach, w których prądu jest już za dużo, ma skłonić do rozsądnego planowania produkcji, co stanowi alternatywę dla niemieckiego modelu, w którym dotacje są płacone zawsze.

Ustawa o OZE z 2015 r. wprowadziła skup energii elektrycznej z odnawialnych źródeł na zasadzie aukcji, które prezes URE ogłasza, organizuje i przeprowadza nie rzadziej niż raz w roku ${ }^{59}$. W pierwszej wersji ustawy o OZE nie było koszyków technologicznych, a jedynie podział na instalacje o łącznej zainstalowanej mocy elektrycznej nie większej niż $1 \mathrm{MW}$ i większej niż $1 \mathrm{MW}^{60}$. Wszystkie źródła rywalizowałyby ze sobą, co rodziło obawy o to, że koszyk powyżej $1 \mathrm{MW}$ zostanie zdominowany przez elektrownie wiatrowe, które cechują się najniższym bezpośrednim jednostkowym kosztem produkcji. W uchwalonej 22 czerwca 2016 r. zmianie ustawy o odnawialnych źródłach energii (weszła w życie 1 lipca) wprowadzono 7 kategorii w ramach obu grup wielkościowych instalacji. Wydzielono m.in. koszyk biogazowni rolniczych czy instalacji o stopniu wykorzystania mocy powyżej $40 \%{ }^{61}$.

Elektrownie wiatrowe (a także fotowoltaiczne, które również cechują się niemożnością dostosowania podaży do popytu) nie ponoszą wspomnianych wcześniej kosztów utrzymywania systemu mocy rezerwowych na czas, gdy warunki pogodowe nie pozwalają na produkcję, co można również potraktować jako formę wsparcia polegającą na zwolnieniu z obowiązku łagodzenia negatywnych skutków ubocznych swojej działalności. Sytuacja taka ma miejsce nie tylko w Polsce. W Niemczech również producentów prądu o zmiennej podaży nie obarcza się kosztami tych zmian, a w tym państwie ma to większe znaczenie z uwagi na duży udział mocy elektrowni wiatrowych i fotowoltaicznych w systemie elektroenergetycznym. Taka sytuacja względnie pogarsza konkurencyjność energii geotermalnej i biomasowej, a częściowo także wodnej.

57 Ustawa z dnia 20 lutego 2015 r. o odnawialnych źródłach energii, art. 46, ust. 4, op.cit.

58 P. Götz et al., Negative Electricity Prices: Causes and Effects An analysis of recent developments and a proposal for a flexibility law, Agora Energiewende, Berlin 2014, s. 1.

59 Ustawa z dnia 20 lutego 2015 r. o odnawialnych źródłach energii, art. 73, ust. 1, op.cit.

60 Ibidem, art. 73 , ust. 4.

61 Ustawa z dnia 22 czerwca 2016 r. o zmianie ustawy o odnawialnych źródłach energii oraz niektórych innych ustaw, art. 1, p. 34, lit. b-c, op.cit. 
Wsparcie określonych źródeł energii ma również inny pośredni wpływ na ich konkurencyjność. Stworzenie bardziej sprzyjających warunków sprawia, że wzrasta popyt na określony typ technologii, co skutkuje polepszaniem się oferty w zakresie danego sektora. Wzrasta bowiem liczba dostawców i konkurencja między nimi, a wzrost zamówień sprawia, że producenci urządzeń mają środki na wprowadzanie ulepszeń, co podnosi konkurencyjność ich rozwiązań. Dotyczy to jednak nie tylko OZE, ale i alternatywnych źródeł energii.

\section{Sieci przesyłowe}

Według Adama Smitha jedną z form interwencji publicznej jest również regulowanie infrastruktury niezbędnej do prowadzenia działalności gospodarczej. Państwo powinno utrzymywać ją w stanie niezbędnym do rozwoju handlu ${ }^{62}$. W tym kontekście należy zwrócić uwagę na fakt, że sektor OZE jest generalnie bardzo rozproszony, zwłaszcza w przypadku instalacji geotermalnych i biomasy, które nie mogą być ogromnymi obiektami ze względu na rozproszenie czynników produkcji ${ }^{63}$. W Polsce system produkcji energii elektrycznej był do tej pory skoncentrowany i głównie ograniczał się do niewielkiej liczby dużych obiektów węglowych położonych często w pobliżu kopalń. W Niemczech panuje większe rozproszenie, ale nadal są spore braki w zakresie rozwoju OZE. Produkcja prądu z odnawialnych źródeł wymaga rozbudowy systemu przesyłowego, aby zapewnić możliwość dostępu do sieci tych obiektów. Obecnie są wciąż duże braki w tej kwestii, szczególnie ważne dla małych producentów, dla których budowa linii łączącej z siecią byłaby bardzo kosztowna w stosunku do całkowitych kosztów inwestycji. Jest to ważne, ponieważ dostęp do sieci odbywa się przez podłączenie do stacji transformatorowej, do której czasami jest daleko od planowanej elektrowni ${ }^{64}$.

Ponadto koszty inwestycyjne w przypadku przynajmniej części źródeł zwiększa konieczność rozwoju sieci przesyłowych dużej przepustowości, gdyż elektrownie wiatrowe i fotowoltaiczne są lokowane w innych regionach niż węglowe. W Niemczech jest to szczególnie istotne w przypadku wiatraków na morzu, które byłyby odległe

62 P. Podsiadło, Pomoc publiczna a konkurencyjność małych $i$ średnich przedsiębiorstw $w$ świetle zaleceń strategii rozwojowych Unii Europejskiej, Wydawnictwo UE w Krakowie, Kraków 2015, s. 15.

63 IRENA, Renewable Power..., op.cit., s.127; R. Bertani, Geothermal Power Generation in the World 2005-2010 Update Report, [w:] Proceedings World Geothermal Congress 2010, Bali, s. 28.

64 J. Dach, Rynek biogazowni w Polsce - ocena i perspektywy, „Czysta Energia” nr V, 2010, s. 38-42. 
od miejsc zużycia energii, w tym mocno uprzemysłowionej Bawarii ${ }^{65}$, zwłaszcza że w Niemczech brakuje sieci łączących północ i południe państwa ${ }^{66}$. Deficyt ma tak dużą skalę, że Niemcy regularnie przesyłają energię z północy na południe poprzez państwa sąsiadujące - Polskę i Czechy oraz Holandię, Belgię i Francję ${ }^{67}$.

Polityka państwowa w odniesieniu do rozwoju sieci przesyłowych musi więc zapewnić sprawiedliwy dostęp do nich oraz proporcjonalny podział kosztów z tego wynikających.

\section{Dotacje do węgla}

Z węgla wytwarza się 41,5\% energii elektrycznej w Niemczech (2014 r. $)^{68}$ i 84,9\% w Polsce (2013 r. ${ }^{69}$, co czyni go głównym źródłem elektryczności w obu państwach. Wsparcie udzielone temu przemysłowi ma więc również znaczący wpływ na konkurencyjność OZE.

Elektroenergetyka węglowa zarówno w Polsce, jak i w Niemczech jest dotowana w sposób pośredni, poprzez dotacje do kopalń, które mogą w ten sposób oferować swoje produkty taniej. Górnictwo węgla jest dotowane na wiele sposobów. Po pierwsze, przedsiębiorstwa górnicze są wspierane bezpośrednio. Zasadniczo w UE pomoc publiczna jest zabroniona w jakiejkolwiek formie, która zakłóca lub grozi zakłóceniem konkurencji poprzez sprzyjanie niektórym przedsiębiorstwom lub produkcji niektórych towarów. Istnieją jednak pewne wyjątki, gdy pomoc publiczna jest lub może być zaakceptowana, jak zaradzenie poważnym zaburzeniom w gospodarce państwa członkowskiego lub ułatwianie rozwoju niektórych działań gospodarczych lub niektórych regionów gospodarczych ${ }^{70}$.

Przed przystąpieniem Polski do UE w 2004 r. bezpośrednia pomoc publiczna dla górnictwa węgla kamiennego odpowiadała kwocie prawie $0,2-0,3 \%$ produktu krajowego brutto. W $2003 \mathrm{r}$. jednak, gdy nastąpił ostatni moment na to, takie wydatki przekroczyły $2 \% \mathrm{PKB}^{71}$. Obecnie pomoc publiczna wynosi kilkaset milionów złotych

65 R. Beveridge, K. Kern, op.cit.

66 E. Bayer, Report on the German..., op.cit., s. 15

67 Ibidem, s. 16.

68 Ibidem, s. 14

69 CIRE, Podstawowe dane, Centrum Informacji o Rynku Energii, 2016, http://www.rynek-energii-elektrycznej.cire.pl/st,33,207, tr,75,0,0,0,0,0, podstawowe-dane.html [dostęp 28.09.2016].

70 Wersja skonsolidowana Traktatu o funkcjonowaniu Unii Europejskiej, art. 107, DzU UE C 326 z 26.10.2012, s. 47-390.

71 M. Bukowski, A. Śniegocki, Ukryty rachunek za węgiel. Analiza wsparcia gospodarczego dla elektroenergetyki węglowej oraz górnictwa w Polsce, Warszawski Instytut Studiów Ekonomicznych, Warszawa 2014 , s. 11. 
rocznie i jest ograniczona do form, które są dozwolone przez UE - głównie prac badawczo-rozwojowych, restrukturyzacji i pomocy związanej ze środowiskiem, takiej jak usuwanie szkód górniczych i likwidacja kopalńn ${ }^{72}$.

Według raportu WiseEuropa polskie górnictwo bez pomocy publicznej nie byłoby w stanie sprostać konkurencji na globalnym rynku bez znacznej restrukturyzacji ${ }^{73}$. Jest ona finansowana $\mathrm{z}$ pomocy publicznej. Wiele firm górniczych dokapitalizowano bezpośrednio lub pośrednio poprzez przekształcenie ich zaległych zobowiązań ${ }^{74}$. Kilka razy zostały umorzone lub odroczone zaległości w płatnościach na wiele miliardów złotych, takie jak składki emerytalne, podatki, składki na Fundusz Gwarantowanych Świadczeń Pracowniczych, a także opłaty środowiskowe, w tym te na potrzeby likwidacji szkód górniczych. Suma różnych dotacji i subwencji w latach 1990-2012 wyniosła 69 mld zt $^{75}$.

Jednakże, jak wspomniano, od polskiej akcesji do UE w 2004 r. powyższe formy wsparcia są mocno ograniczone i stanowią małą część pomocy publicznej dla sektora węglowego w Polsce.

Inną formą pomocy publicznej są dotacje do specjalnego systemu emerytur górniczych. Zgodnie z przepisami górnicy otrzymują niewspółmiernie wyższe emerytury w stosunku do ich składek emerytalnych aniżeli pracownicy innych branż. Zgodnie z ustawą o emeryturach i rentach z Funduszu Ubezpieczeń Społecznych ich emerytury są mnożone przez współczynnik wynoszący 1,2-1,8 - w zależności od konkretnego rodzaju pracy ${ }^{76}$. Ponadto górnicy w Polsce mają prawo do przejścia na emeryturę znacznie wcześniej niż pracownicy innych branż ${ }^{77}$. Skutkuje to dłuższym okresem pobierania emerytury, co powoduje wyższe koszty dla systemu społecznego. Według szacunków WiseEuropa (z 2013 r.) na każdą złotówkę wypłacaną przez górników państwo płaci dodatkowo $1,52 \mathrm{zł}$ na ten cel, co jest kolejną formą dotacji ${ }^{78}$.

Szacuje się, że w 2012 r. wymienione formy wsparcia odpowiadały za około 6\% hurtowej ceny energii elektrycznej w Polsce ${ }^{79}$.

W Niemczech węgiel też jest subsydiowany. Wynika to z faktu, iż węgiel kamienny wydobywany w kraju jest droższy od importowanego. Dlatego, by utrzymać opłacalność

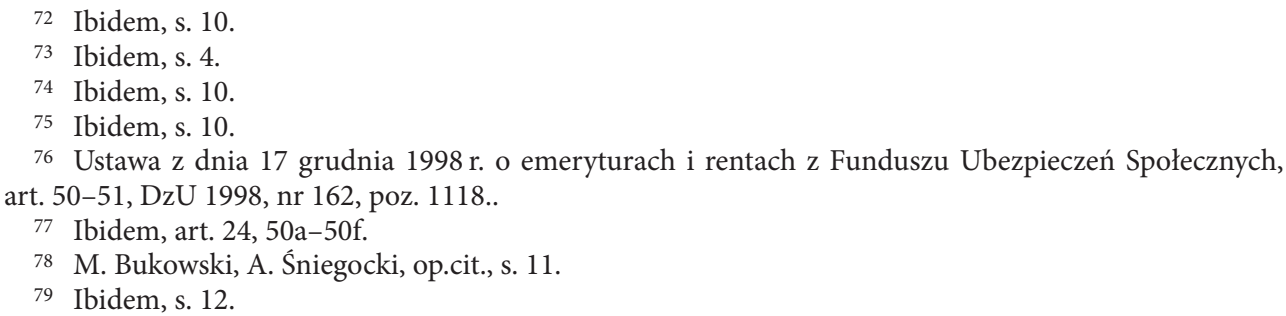


swojego górnictwa, Niemcy dotują kopalnie, płacąc im różnicę w kosztach ${ }^{80}$. Pieniądze trafiają do spółki RAG Deutsche Steinkohle AG, która prowadzi całe wydobycie węgla kamiennego w Niemczech ${ }^{81}$. Firma ta otrzymuje również środki na zamykanie kopaln $^{82}$. Wsparcie ma również formę zwolnień z podatków, m.in. opłat od wydobycia surowców ${ }^{83}$. Całkowita kwota wsparcia dla przemysłu węglowego w Niemczech jednak systematycznie spada. W $1991 \mathrm{r}$. wynosiła równowartość ponad 5 mld euro, a w 2011 r. już tylko 1,9 mld euro ${ }^{84}$. W 2007 r. rząd federalny, rządy landów, w których znajdują się kopalnie, związki zawodowe oraz RAG uzgodnili mapę drogową mającą na celu zakończenie subsydiowania węgla w społecznie akceptowalny sposób do końca $2018 \mathrm{r}^{85}$

Najważniejsza forma wspierania energii opartej na węglu jest związana $\mathrm{z}$ jego zewnętrznym wpływem. Spalanie węgla ma niezwykle szkodliwy wpływ na zdrowie publiczne (oraz na środowisko). Wynikające stąd koszty związane są m.in. ze zwolnieniami chorobowymi, rentami dla osób niezdolnych do pracy czy wyższymi wydatkami na leczenie ${ }^{86}$. Koszty te są szacowane na 2,303-6,385 mld euro rocznie w Niemczech i 2,979-8,219 mld euro w Polsce ${ }^{87}$. Wartość dla Polski jest najwyższa w całej UE (dla UE-27 koszty oszacowano na 15,453-42,811 mld euro), mimo że Niemcy mają ponad dwa razy więcej ludności. Jednakże nawet te koszty nie są wyczerpujące, ponieważ nie uwzględniają konsekwencji neurologicznych szkód związanych z uwalnianiem rtęci, które są odpowiedzialne za 8-9 mld euro kosztów leczenia rocznie w całej $\mathrm{UE}^{88}$. Nie obejmują one również wszystkich skutków zdrowotnych w cyklu gospodarowania węglem, takich jak te związane z jego wydobyciem i transportem oraz unieszkodliwianiem odpadów ${ }^{89}$. Należy także wziąć pod uwagę skutki kwaśnych deszczy, wywoływanych zawartością siarki w spalanym węglu. Takie deszcze powodują m.in. szybszą degradację budynków czy pogorszenie jakości plonów w rolnictwie. W polskim badaniu z 2014 r. oszacowano, że koszty zewnętrzne spalania węgla w polskich elektrowniach powinny być zrekompensowane dodatkową

80 OECD, Germany: inventory of estimated budgetary support and tax expenditures for fossil-fuels - 2013, 2013, http://www.oecd.org/site/tadffss/DEU.pdf [dostęp 30.09.2016], s. 2.

81 Ibidem, s. 1.

82 Ibidem, s. 2.

83 Ibidem, s. 7.

84 Ibidem, s. 3 .

85 Ibidem, s. 2.

86 M. Bukowski, A. Śniegocki, op.cit., s. 14.

87 J. Huscher, D. Smith, The unpaid health bill. How coal power plants make us sick, Health and Environment Alliance, Brussels 2013, s. 26.

88 Ibidem, s. 25.

89 Ibidem. 
opłatą wynoszącą od około 0,1 do $0,5 \mathrm{zz} / \mathrm{kWh}^{90}$. Jednakże również to badanie nie obejmuje wszystkich kosztów, np. tych związanych ze zmianami klimatu ${ }^{91}$. Najbardziej wszechstronne studium w tym zakresie wykonane dla USA w 2011 r. wskazuje, że w tym państwie całkowity koszt energii elektrycznej z węgla powinien być wyższy o $0,178 \mathrm{USD} / \mathrm{kWh}(0,16 \text { euro lub } 0,7 \mathrm{zł})^{92}$.

Dla porównania, według Eurostatu w 2016 r. ceny prądu dla średniej wielkości gospodarstwa domowego w Polsce wynosiły 0,1332 euro/kWh i 0,2969 euro/kWh w Niemczech, zaś dla średniej wielkości odbiorcy przemysłowego 0,0762 euro/kWh w Polsce i 0,0788 euro/kWh w Niemczech ${ }^{93}$. Oznacza to, że jeżeli sektor energetyczny musiałby być w pełni odpowiedzialny za wszystkie koszty efektów zewnętrznych swojej działalności, ostateczna cena prądu z elektrowni węglowych dla klientów byłaby wiele wyższa, a przypadku odbiorców przemysłowych około trzykrotnie w obu państwach. Należy przy tym pamiętać, że na cenę prądu dla klientów składa się nie tylko kwota dla elektrowni, ale i dla operatora sieci oraz różne daniny dla państwa. W Polsce hurtowa cena energii, czyli kwota, jaką otrzymują jej producenci, to w $2016 \mathrm{r}$. zaledwie $0,17 \mathrm{zl}(0,04 \text { euro })^{94}$. Tak więc prawdziwe koszty wytwarzania elektryczności z węgla są kilkakrotnie wyższe od tych, które są ponoszone przez elektrownie.

Przy ocenie publicznego wsparcia warto również wziąć pod uwagę perspektywy dla skali zapotrzebowania na nie. Technologie OZE są cały czas ulepszane i ich koszty jednostkowe maleją, co sprawia, że z roku na rok wymagają coraz mniejszych dotacji ${ }^{95}$. Przemysł węglowy spotyka się z odmienną sytuacją. Eksploatacja węgla w naturalny sposób wiąże się z koniecznością schodzenia coraz głębiej w celu jego wydobywania, co znacznie podnosi koszty surowca do produkcji prądu w elektrowniach węglowych. Co więcej, dzieje się tak mimo działań restrukturyzacyjnych. Stopień nierentowności kopalń nie maleje ${ }^{96}$ i dlatego wsparcie powinno tu być kierowane w stronę źródeł, które w przyszłości mogą wymagać go jak najmniej.

90 M. Bukowski, A. Śniegocki, op.cit., s. 13.

91 Ibidem, s. 9.

92 P.R. Epstein et al., Full cost accounting for the life cycle of coal, „Annals of the New York Academy of Sciences”, „Ecological Economics Reviews” No. 1219, 2011, s. 93.

93 Eurostat, Electricity prices by type of user, 2016, http://ec.europa.eu/eurostat/tgm/table.do?tab=table\&init $=1 \&$ language $=$ en\&pcode $=$ ten00117\&plugin $=1$ [dostęp30.09.2016] .

94 Cena prądu, Ceny prądu w Polsce, 2016, http://www.cenapradu.strefa.pl/ [dostęp 30.09.2016].

95 M. Bukowski, A. Śniegocki, op.cit., s. 16.

96 Ibidem, s. 6. 


\section{Wpływ na opinię publiczną}

Dla odbiorców energii elektrycznej najważniejszym czynnikiem jest jego zakup po możliwie najniższych kosztach, jednakże obawiają się oni również o to, że zmiana dostawcy może spowodować przerwy w zaopatrzeniu ${ }^{97}$. Doświadczenie rynków energetycznych z państw, gdzie jest obecnych wielu konkurentów (jak Wielkiej Brytanii), pokazuje, że im dłużej dywersyfikacja rynku ma miejsce, tym więcej klientów wie o możliwości zmian i bardziej są oni chętni skorzystać z niej, zmieniając dostawcę ${ }^{98}$. Ze względu na podział pomiędzy właścicielami instalacji produkcyjnych i systemu dystrybucji, dystrybutorzy w takiej sytuacji wywierają nacisk na producentów i są pod wpływem tych zmian. W warunkach wspierania skoncentrowanych producentów trudniej jest mieć wpływ na nich. Ponadto dla producentów odnawialnych trudniej jest konkurować z nimi poprzez niższą cenę, którą elektrownie węglowe oferują dzięki specjalnej pomocy państwa. Stosunkowo niskie korzyści ze zmiany dostawcy powodują zaś, że klienci są mniej zainteresowani w poszukiwaniu tańszych. W rezultacie rynek energii elektrycznej doświadcza mniejszej presji na poszukiwanie alternatywnych dostawców.

Ponadto ukryte wsparcie dla przemysłu węglowego i bardziej jawne dla niektórych OZE (bilansowanie) tworzy niejasną sytuację dla opinii publicznej. Społeczeństwo może odnieść wrażenie, że OZE są bardziej kosztowne niż węgiel, co przeinacza obraz dla decydentów, którzy pod wpływem opinii publicznej mogą być niechętnie nastawieni do zmiany obecnej sytuacji ${ }^{99}$.

\section{Ogólne warunki do prowadzenia działalności gospodarczej}

Zarówno Polska, jak i Niemcy oferują na tle reszty świata dobre warunki do prowadzenia działalności gospodarczej (patrz tab. 1). Na 189 państw sklasyfikowanych w rankingu Doing Business w 2016 r Polska znalazła się na 25 miejscu pod względem łatwości prowadzenia biznesu, a Niemcy na 15. Między poszczególnymi kategoriami widać jednak zróżnicowanie. Oba państwa relatywnie kiepsko wypadają w kategorii

97 PWC, ING, Koniec tradycyjnej energetyki? Jak wygrać w dobie zmian?, 2015, s. 18-20.

98 Ibidem, s. 19.

99 M. Bukowski, A. Śniegocki, op.cit., s. 6. 
rozpoczęcia działalności, choć w stosunku do światowego lidera notują dobre wyniki. Uzyskanie pozwolenia na budowę jest łatwe w Niemczech, w Polsce nieco trudniejsze. Istotną pozycją dla sektora produkcji energii elektrycznej jest punkt dotyczący podłączenia do prądu. Dotyczy on wprawdzie podłączania konsumentów, jednak daje pewien obraz na temat administracji i szybkości działania operatorów sieci przesyłowych. W Niemczech warunki w tym zakresie są jednymi z najlepszych na świecie (3 miejsce), Polska jednak zajmuje dopiero 49 pozycję. W obu państwach wiele do poprawienia jest jeszcze w kategoriach rejestracji własności, ochrony mniejszych inwestorów i płacenia podatków. Niemcy bardzo dobrze wypadają zaś w kwestiach egzekwowania umów i rozstrzygania upadłości, a Polska w prowadzeniu handlu międzynarodowego i dobrze w uzyskiwaniu kredytów.

Tabela 1. Czynniki warunkujące łatwość prowadzenia działalności gospodarczej w Polsce i w Niemczech

\begin{tabular}{|l|c|c|c|c|}
\hline \multirow{2}{*}{\multicolumn{1}{|c|}{ Czynnik }} & \multicolumn{2}{|c|}{ Polska } & \multicolumn{2}{c|}{ Niemcy } \\
\cline { 2 - 5 } & $\begin{array}{c}\text { miejsce } \\
\text { w rankingu } \\
\text { (na 189) }\end{array}$ & $\begin{array}{c}\text { punktacja (najlepszy } \\
\text { w rankingu = 100) }\end{array}$ & $\begin{array}{c}\text { miejsce } \\
\text { w rankingu } \\
\text { (na 189) }\end{array}$ & $\begin{array}{c}\text { punktacja (najlepszy } \\
\text { w rankingu = 100) }\end{array}$ \\
\hline Rozpoczęcie działalności & 85 & 85,94 & 107 & 83,37 \\
\hline Uzyskanie pozwolenia na budowę & 52 & 74,24 & 13 & 81,42 \\
\hline Podłączenie do prądu & 49 & 80,15 & 3 & 98,78 \\
\hline Zarejestrowanie własności & 41 & 75,65 & 62 & 69,35 \\
\hline Uzyskanie kredytu & 19 & 75,00 & 28 & 70,00 \\
\hline Ochrona mniejszych inwestorów & 49 & 60,00 & 49 & 60,00 \\
\hline Płacenie podatków & 58 & 79,63 & 72 & 77,00 \\
\hline Handel międzynarodowy & 1 & 100,00 & 35 & 91,77 \\
\hline Egzekwowanie umów & 55 & 63,44 & 12 & 75,08 \\
\hline Rozstrzyganie upadłości & 32 & 70,43 & 3 & 91,93 \\
\hline Ogólny wynik & 25 & 76,45 & 15 & 79,87 \\
\hline
\end{tabular}

Źródło: World Bank Group, Doing Business 2016. Measuring Regulatory Quality and Efficiency. Economy Profile 2016. Poland, s. 8, 11-15.

\section{Podsumowanie i wnioski}

Uwarunkowania prawne i polityczne w znaczący sposób oddziałują na konkurencyjność wytwarzania energii elektrycznej z OZE w Polsce i w Niemczech (patrz rys. 1).

Wśród najważniejszych czynników można wyróżnić wsparcie dla bieżącej produkcji. W Polsce ma ono formę certyfikatów pochodzenia, które są zobowiązani 
kupować dystrybutorzy energii i najwięksi konsumenci, a w Niemczech są taryfy gwarantowane, zapewniające określony zysk każdemu, kto wytworzy energię odnawialną. Budowa instalacji jest także wspierana, choć znaczna część dotacji pochodzi z UE.

Rysunek 1. Oddziaływanie warunków prawnych i politycznych na konkurencyjność wytwarzania elektryczności z OZE w Polsce i Niemczech względem węgla

Rząd
Polska
- Świadectwa pochodzenia OZE - dodatkowy dochód dla producentów prądu
- Dotacje do górnictwa węglowego - restrukturyzacyjne
- Preferencyjny system emerytalny dla górników
- Taryfy gwarantowane dla OzE - dopłaty od 2017 r. częściowo w formie aukcji
- Dotacje do górnictwa węglowego - wyrównywanie
- Zwolnienie z obowiązku tagodzenia negatywnych konsekwencji spalania węgla
- Zwolnienie z obowiązku tagodzenia negatywnych konsekwencji bilansowania niektórych OzE
- Całkiem dobre ogólne warunki administracyjno-proceduralne do rozpoczęcia działalności gospodarczej

Strategia, struktura i rywalizacja firm
Polska
- Sektor pozostaje mniej skoncentrowany
- mniej konkurentów
Niemcy
- Sektor się rozprasza
Polska/Niemcy
- W warunkach konkurencji cenowej
wspierany węgiel jest w relatywnie lepszej
sytuacji

\section{Sektory pokrewne i wspierające} Polska

- Dostawcy węgla są wspierani i moga oferować tańszy produkt elektrowniom Niemcy

- Dostawcy węgla są coraz mniej wspierani Polska/Niemcy

- Wsparcie OzE stymuluje ulepszanie technologii przez dostawców

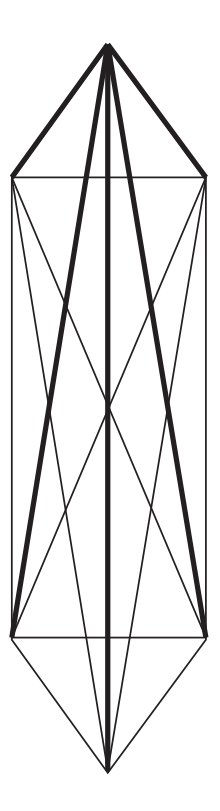

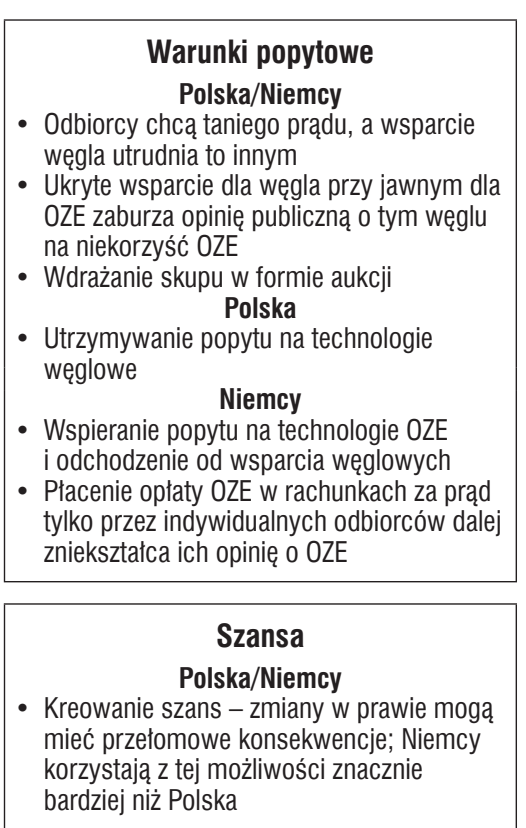
bardziej niż Polska

\section{Warunki czynników produkcji}

\section{Polska}

- Ułatwianie wykorzystania zasobów węgla, które normalnie nie mogłyby być eksploatowanie w opłacalny sposób Niemcy

- Infrastruktura przesyłowa jest dostosowana do elektrowni starego systemu - dużych, a ta potrzebna do OZE jest rozbudowywania bardzo powoli w stosunku do potrzeb

Źródło: Opracowanie własne. 
Wsparcie rządu jest kierowane jednak także do alternatywnych wobec OZE źródeł energii, jest to przede wszystkim zwłaszcza do węgiel. Odbywa się to w pośredni sposób, poprzez wsparcie dostawców elektrowni, czyli kopalni. W Polsce zasadnicze dotacje przyjmują głównie formę subsydiowania emerytur i rent górniczych; dotacje restrukturyzacyjne przybierają znacznie mniejszą skalę. W Niemczech subsydiowanie węgla służy pokrywaniu części wysokich kosztów, niekonkurencyjnych względem zagranicy, jednak od tego się już odchodzi. W obu państwach najważniejszą i najbardziej ukrytą formą wsparcia elektroenergetyki węglowej jest zwolnienie jej z obowiązku łagodzenia negatywnych konsekwencji swojej działalności. Zanieczyszczenie powietrza spalaniem węgla generuje ogromne koszty leczenia chorób nim wywołanych, jak również wiele innych skutków, m.in. zniszczenia na skutek kwaśnych deszczy. Koszty te są opłacane z budżetu państwa, a nie przez winowajcę. Gdyby elektrownie węglowe musiały brać pełnię odpowiedzialności za swoją działalność, ich koszty wzrosłyby kilkakrotnie.

Ukryte wsparcie $\mathrm{w}$ formie zwolnienia $\mathrm{z}$ konieczności łagodzenia negatywnych skutków swojej działalności odnosi się także do niektórych OZE - tych o podaży prądu niedającej się dostosować do popytu, czyli przede wszystkim elektrowni wiatrowych i fotowoltaicznych. Nie muszą one płacić za utrzymywanie rezerwowych mocy na czas, gdy warunki pogodowe nie pozwalają im działać. Jest to również forma wsparcia, której brak znacząco podniósłby koszty i względnie podwyższyłby konkurencyjność energii geotermalnej i biomasowej, a częściowo także wodnej.

Ukryte wsparcie spalania węgla i niektórych OZE wprowadza w błąd opinię publiczną, która uzyskuje niemiarodajny obraz rzeczywistości i jest gotowa popierać poszczególne źródła w innym stopniu, niż gdyby to miało miejsce przy pełnej wiedzy. Opinię publiczną w Niemczech zaburza fakt, iż taryfy gwarantowane są finansowane z opłaty OZE, zawartej w rachunku za prąd, którą płacą niemal wyłącznie odbiorcy indywidualni, na skutek tego obarczani nią nieproporcjonalnie do ich zużycia i mogący przez to bardziej negatywnie postrzegać OZE.

Także infrastruktura przesyłowa, nad którą państwo trzyma pieczę, jest dostosowana do tradycyjnego systemu elektroenergetycznego, opartego na mniejszej liczbie większych obiektów. Dla rozproszonego systemu OZE generuje to spore bariery wejścia i znacznie wpływa na opłacalność.

Wsparcie węgla, w zakresie takim, jak ma miejsce w Polsce, przy jednoczesnym ograniczonym wsparciu dla OZE, skutkuje mniejszym rozproszeniem sektora. W sytuacji, w której rywalizacja odbywa się głównie cenowo, szczególnie zakłóca to konkurencję. W Niemczech zaś wsparcie dla OZE jest na tyle wysokie, że skłania do szerokiego inwestowania i rozproszony sektor cechuje się tam znacznie większą ostrością konkurencji. 
Rządy również pośrednio oddziałują na konkurencyjność, stymulując popyt na różne technologie i przez to doprowadzając do ich rozwoju i obniżania kosztów. W Polsce w dużym stopniu jest wspierany w ten sposób jest węgiel (ale OZE też), a w Niemczech przede wszystkim OZE, zaś węgiel jest tam jawnym celem do redukcji.

Rząd ma również okazję dokonywania na rynku nagłych zmian poprzez odpowiednie uregulowania, co może w znaczący sposób wpływać na konkurencyjność poszczególnych źródeł i dawać im nowe szanse. W Niemczech odbywa się to w dużym stopniu i na korzyść OZE. W Polsce zmiany są rzadsze i mniej pomagają odnawialnym źródłom. Ogólne warunki administracyjno-proceduralne do rozpoczęcia działalności gospodarczej są jednak w obu państwach całkiem dobre; w Niemczech nieco lepsze.

Uwarunkowania prawne i polityczne do rozwoju produkcji energii elektrycznej z OZE zarówno w Polsce, jak i w Niemczech bardzo silnie oddziałują na konkurencyjność tego sektora. Niemcy stwarzają jednak znacznie korzystniejsze warunki do rozwoju tego sektora. W regulacjach prawnych i działaniach rządu widać odzwierciedlenie deklarowanego kierunku zmian. W Polsce, mimo że OZE przeżywają względny rozkwit, wciąż warunki są niedostateczne w stosunku do możliwości, a jest to efektem niedostatecznego zainteresowania rządów energetyczną transformacją. W obu państwach przyjęte rozwiązania napotykają jednak poważne problemy. W Polsce nadpodaż certyfikatów pochodzenia spowodowała spadek ich wartości, co znacznie obniżyło zyskowność inwestycji w OZE, zaś w Niemczech rozwój tańszych technologii, jakimi są fotowoltaika i wiatraki, rozregulował stabilność systemu elektroenergetycznego.

\section{Literatura}

Bayer E., Report on the German power system, Agora Energiewende, Berlin 2014.

Bayer W., Energie auf einen Blick, Statistisches Bundesamt, Wiesbaden 2009.

Bertani R., Geothermal Power Generation in the World 2005-2010 Update Report, [w:] Proceedings World Geothermal Congress 2010, Bali, s. 1-41.

Beveridge R., Kern K., The 'Energiewende' in Germany: Background, Development and Future Challenges, „Renewable Energy Law and Policy Review” Vol. 4, Iss. 1, 2013.

Buchan D., The Energiewende - Germany's gamble, Oxford Institute for Energy Studies, Oxford 2012.

Bundesnetzagentur, Pressemitteilung. EEG-Umlage auf stabilem Niveau, Bonn 2015, 15.10.2015.

Cena prądu, Ceny prądu w Polsce, 2016, http://www.cenapradu.strefa.pl/ 
CIRE, Podstawowe dane, Centrum Informacji o Rynku Energii, 2016, http://www.rynek-energii-elektrycznej.cire.pl/st,33,207, tr,75,0,0,0,0,0, podstawowe-dane.html

Dach J., Rynek biogazowni w Polsce - ocena i perspektywy, „Czysta Energia” nr V, 2010, s. 38-42.

Dyrektywa Parlamentu Europejskiego i Rady 2009/28/WE z dnia 23 kwietnia 2009 r. w sprawie promowania stosowania energii ze źródeł odnawialnych zmieniająca i w następstwie uchylająca dyrektywy 2001/77/WE oraz 2003/30/WE,DzU UE L 140 z 5.06.2009, s. $16-62$, zał. 1.

Epstein P.R. et al., Full cost accounting for the life cycle of coal, "Annals of the New York Academy of Sciences”, „Ecological Economics Reviews” No. 1219, 2011, s. 73-98.

Eurostat, Electricity generated from renewable sources, 2016, http://ec.europa.eu/eurostat/ $\mathrm{tgm} / \mathrm{table} . \mathrm{do}$ ?tab=table\&init $=1$ \&language $=$ en $\&$ pcode $=$ tsdcc330\&plugin $=1$

Eurostat, Electricity prices by type of user, 2016, http://ec.europa.eu/eurostat/tgm/table. do? tab $=$ table\&init $=1 \&$ language $=$ en $\&$ pcode $=$ ten $00117 \&$ plugin $=1$

Federal Ministry for Economic Affairs and Energy, Making a success of the energy transition, Berlin 2015.

Götz P. et al., Negative Electricity Prices: Causes and Effects An analysis of recent developments and a proposal for a flexibility law, Agora Energiewende, Berlin 2014.

Graniszewska M., Polska kontra świat i liczby, „Puls Biznesu” nr 43, 2016, s. 8.

Graniszewska M., Szef PGNiG gotów gasić światło w łupkach, „Puls Biznesu” nr 88, 2016, s. 4.

GUS, Energia ze źródeł odnawialnych w 2013 r., Warszawa 2014.

GUS, Energia ze źródeł odnawialnych w 2014 r., Warszawa 2015.

HuscherJ., Smith D., The unpaid health bill. How coal power plants make us sick, Health and Environment Alliance, Brussels 2013.

IAR, Tchórzewski: Rząd będzie wspierat biogazownie, Bankier.pl, 28 grudnia 2015, http://www. bankier.pl/wiadomosc/Tchorzewski-Rzad-bedzie-wspieral-biogazownie-3462840.html

IRENA, Renewable Energy Prospects: Germany, REmap 2030 analysis, International Renewable Energy Agency (IRENA), Abu Dhabi 2015.

IRENA, Renewable Power Generation Costs 2014, International Renewable Energy Agency, Bonn 2015.

Julien F., Lamla M., Competitiveness of Renewable Energies Comparison of Major European Countries, European University Viadrina Frankfurt (Oder), Department of Business Administration and Economics, „Discussion Paper” No. 302, 2011.

Krause F., Bossel H., Müller-Reißmann K.F., Energie-Wende: Wachstum und Wohlstandohne Erdöl und Uran, Frankfurt am Main 1980.

Morris C., Chapter 7 - Germany's Energiewende: Community-Driven Since the 1970s, [w:] Global Sustainable Communities Handbook. Green Design Technologies and Economics, red. C. Woodrow, Elsevier 2014, s. 105-113. 
OECD, Germany: inventory of estimated budgetary support and tax expenditures for fossil-fuels - 2013, 2013, http://www.oecd.org/site/tadffss/DEU.pdf

Olszyński J., Nowe elementy w relacjach polsko-niemieckich w zakresie polityki europejskiej, [w:] Nowe zjawiska w gospodarce Niemiec i polsko-niemieckich stosunkach gospodarczych, red. J. Olszyński, A. Bielig, Oficyna Wydawnicza SGH, Warszawa 2014, s. 565-577.

Podsiadło P., Pomoc publiczna a konkurencyjność matych iśrednich przedsiębiorstw w świetle zaleceń strategii rozwojowych Unii Europejskiej, Wydawnictwo UE w Krakowie, Kraków 2015.

Popławski T., Dąsal K., Łyp J., Problematyka prognozowania mocy i energii pozyskiwanych $z$ wiatru, „Polityka Energetyczna” t. 12, z. 2/2, 2009, s. 511-523.

Porter M.E., The competitive advantage of nations, Macmillan Press, London, Basingstoke 1991.

PWC, ING, Koniec tradycyjnej energetyki? Jak wygrać w dobie zmian?, 2015.

Ustawa z dnia 17 grudnia 1998 r. o emeryturach i rentach z Funduszu Ubezpieczeń Społecznych, DzU 1998, nr 162, poz. 1118.

Ustawa z dnia 20 lutego 2015 r. o odnawialnych źródłach energii, DzU 2015, poz. 478.

Ustawa z dnia 22 czerwca 2016 r. o zmianie ustawy o odnawialnych źródłach energii oraz niektórych innych ustaw, DzU 2016, nr 0, poz. 925.

Ustawa z dnia 29 grudnia 2015 r. o zmianie ustawy o odnawialnych źródłach energii oraz ustawy - Prawo energetyczne, DzU 2015, poz. 2365.

Wersja skonsolidowana Traktatu o funkcjonowaniu Unii Europejskiej, DzU UE C 326 z 26.10.2012, s. 47-390.

Wirth H., Recent Facts about Photovoltaics in Germany, Fraunhofer ISE, Freiburg 2016.

World Bank Group, Doing Business 2016, Measuring Regulatory Quality and Efficiency. Economy Profile 2016. Poland, http://www.doingbusiness.org/data/exploreeconomies/ / media/giawb/doing\%20business/documents/profiles/country/POL.pdf

\section{Legal and political conditions influence on the competitiveness of RES production in Poland and Germany}

The aim of this paper is to analyse how legal and political conditions in Poland and Germany affect the competitiveness of renewable energy (RES) production. The analysis also includes the most important competitive source of energy in both countries, namely coal. An attempt to assess the influence of governments on the RES sector by influencing carbon-based energy was also made. The framework of this analysis is expanded diamond of M.E. Porter's competitive advantage of 
nations, although its scope was limited to the governmental factor and its influence on the other components of the model. The analysis shows great importance of legal and political conditions for the competitiveness of RES in both countries, including enormous impact of hidden support for coal, and indicates disadvantages of the methods of RES subsidising.

Keywords: power generation, law, politics, competitiveness, renewable energy sources, Poland, Germany.

\section{L'environnement juridique et politique et la compétitivité du secteur des énergies renouvelables en Pologne et en Allemagne}

L'objectif de l'article consiste à analyser les conditions juridiques et politiques en Pologne et en Allemagne ela compt leur impact sur la compétitivité de la production d'énergie renouvelable (RES). L'analyse comprend également la plus importante source d'énergie compétitive dans les deux pays, à savoir le charbon. L'auteur tente également d'évaluer l'influence que peuvent exercer les gouvernements sur le secteur RES en promouvant l'énergie à base de charbon. Le cadre de l'analyse est le modèle du diamant de M.E. Porter expliquant pourquoi certaines nations sont plus compétitives que d'autres, bien que sa portée soit limitée au seul facteur gouvernemental et son influence sur les autres composantes du modèle. Les résultats de l'analyse montrent l'importance qu'ont les conditions juridiques et politiques en ce qui concerne la compétitivité des énergies renouvelables dans les deux pays, y compris le soutien caché accordé au charbon. Ils nt démontrent également les inconvénients des méthodes de subventionner les RES mises en pratique à présent.

Mots-clés: production d'énergie, loi, politique, compétivité, source d'énergie renouvelables, Pologne, Allemagne.

\section{Юридические и политические условия и конкурентоспособность сектора возобновляемой энергии в Польше и Германии}

Целью статьи является анализ, как правовые и политические условия в Польше и в Германии влияют на конкурентоспособность производства энергии на основе возобновляемых источников. Анализ включает также 
важнейший конкурентный источник энергии в обеих странах - уголь. Была также предпринята попытка оценки влияния правительств на сектор ВИЭ путем воздействия на производство энергии из угля. Основой для этого анализа послужил расширенный ромб конкурентного преимущества стран М.Э. Портера, хотя его объем был ограничен только до правительственного фактора и его влияния на другие компоненты модели. Результаты анализа показали большое значение правовых и политических условий для конкурентоспособности ВИЭ в обеих странах, учитывая огромное влияние скрытой поддержки угля. Они также указывают на недостатки применяемых методов субсидирования ВИЭ.

Ключевые слова: выработка электроэнергии, право, политика, конкурентоспособность, возобновляемые источники энергии, Польша, Германия. 